\title{
Eksistensi Pendidikan Pesantren di Kota Palembang
}

\author{
Muhammad Reza Arviansyah \\ Universitas Sriwijaya \\ mrezaarvian@gmail.com
}

\begin{abstract}
Abstrak
Pendidikan pesantren merupakan salah satu lembaga pendidikan yang keberadannya itu telah ada cukup lama di wilayah Indonesia, tentunya sebagai salah satu lembaga pendidikan yang berbasis agama Islam. Maka sudah seharusnya pesantren ini masih dapat tetap eksis dalam ruang lingkup pendidikan Indonesia karena mayoritas masyarakat Indonesia yang menganut atau memeluk agama Islam. Tujuan penelitian ini untuk mengetahui perkembangan dan eksistensi pesantren di Kota Palembang. Untuk itu penulis akan membahas mengenai lembaga pendidikan pesantren secara umum dan beberapa pesantren yang ada di Kota Palembang. Adapun mengenai metode yang digunakan yakni studi pustaka dengan mengumpulkan data-data tertulis yang ada dan melakukan analisis terhadap data yang telah dikumpulkan, sehingga data yang diambil memiliki kesesuaian dengan tema yang dibahas. Hasil penelitian menunjukkan bahwa pendidikan pondok pesantren di Kota Palembang ada dua, yaitu pondok pesantren yang menerapkan sistem pendidikan shalafiyah dan di lain pihak ada yang menerapkan sistem pendidikan khalafiyah.
\end{abstract}

Kata Kunci : Eksistensi, Pendidikan, Pondok Pesantren, Kota Palembang

\begin{abstract}
Pesantren education is one of the educational institutions whose existence has existed for quite a long time in the territory of Indonesia, of course, as one of the educational institutions based on the Islamic religion. So this pesantren should still exist within the scope of Indonesian education because the majority of Indonesian people adhere to or embrace Islam. The purpose of this study was to determine the development and existence of Islamic boarding schools in Palembang City. For this reason, the author will discuss Islamic boarding schools in general and several Islamic boarding schools in Palembang City. As for the method used, namely literature study by collecting existing written data and analyzing the data that has been collected, so that the data taken has conformity with the themes discussed. The results of the study indicate that there are two Islamic boarding schools in Palembang, namely Islamic boarding schools that apply the education system shalafiyah and on the other hand there are those who apply the education system khalafiyah.
\end{abstract}

Keywords: Existence, Education, Islamic Boarding School, Palembang City 


\section{Pendahuluan}

Jika memahami arti dari eksistensi, mengacu pada kamus besar bahasa indonesia eksistensi memiliki arti keberadaan (Agustin, n.d.). Yang mana berarti bahwa eksistensi disini merupakan sebuah keberadaan yang dari dahulu hingga sekarang ini masih tetap ada bahkan diakui oleh orang lain. Maka seperti yang kita ketahui jika merujuk pada eksistensi dari pendidikan pesantren itu sendiri, pesantren ini telah lama ada dan berkembang di Indonesia. Sebagai salah satu lembaga pendidikan Islam yang masih ada dan dikenal hingga saat ini menunjukkan bahwa pesantren masih bisa beradaptasi dengan kemajuan dan eksis sebagai salah satu lembaga pendidikan yang ada di Indonesia. Untuk itu disini akan dibahas mengenai bagaimana sejarah dari perkembangan pendidikan pesantren itu sendiri.

Pesantren atau yang lebih dikenal dengan pondok pesantren merupakan salah satu lembaga pendidikan Islam yang khas di Indonesia. Yang mana hal ini didukung oleh tidak terdapatnya pendidikan dengan nama dan sistem yang serupa di berbagai negara-negara Islam lain. Yang masih menjadi perdebatan ialah belum diketahuinya secara pasti mengenai sejarah dari awal mula pendirian dan keberadaan dari Pesantren ini di Indonesia, namun yang dapat menjadi bukti pasti bahwa pesantren ini sendiri mulai ada di Indonesia setelah agama Islam masuk di Indonesia menurut beberapa sumber yang mengatakan. Yang mana dilihat dari dalam arti yang luas pendidikan Islam yakni pesantren itu sendiri muncul seiring dengan upaya dari proses islamisasi itu sendiri (Masyhud, 2003)

Menilik kembali untuk dilihat secara pasti mengenai tahun munculnya sebuah pesantren di Indonesia, maka tidak ditemukan secara tepat mengenai lokasi dan waktu pastinya. Hal ini karena pendidikan pesantren merupakan salah satu lembaga pendidikan tradisional yang berkembang di daerah-daerah desa yang terletak di pedalaman. Dan yang perlu diketahui bahwa sejarah dari perkembangan pesantren di Indonesia ini erat kaitannya dengan sejarah dari Islam di Indonesia. Hal ini selaras seperti yang telah disinggung diatas yaitu pesantren merupakan salah satu sarana dari dakwah penyebaran agama Islam. Terlebih lagi pada masa penyebaran Islam atau proses islamisasi di pulau Jawa yang dilakukan oleh para Wali (Anam, 2017)

Dilihat dari kisah berdirinya pesantren tentunya tidak terlepas dari proses islamisasi yang terjadi di Indonesia atau awal mula masuknya agama Islam pertama kali di nusantara pada abad ke-13. Dalam awal pendiriannya pesantren ini banyak mengadopsi budaya- 
budaya masyarakat yang bersifat kedaerahan dan sederhana. Pendidikan pesantren ini memiliki peran dan juga kontribusi yang penting dalam sejarah pembangunan pendidikan di Indonesia. Sebelum masuknya penjajah atau kolonial asing yang datang ke Indonesia, pesantren ini merupakan salah satu lembaga pendidikan yang bertindak sebagai penyebar dari ajaran agama Islam dan mengajak para masyarakat pribumi pada saat itu untuk menghentikan berbagai kepercayaan kuno dengan beralih kepada ajaran Allah SWT melalui amalan yang ada pada kitab suci Al-Quran dan hadist sebagai pedoman untuk membawa perubahan yang lebih baik (Sudrajat, 2018).

Lembaga pendidikan Islam atau Pesantren disini mengandung arti yakni sebuah jenis pendidikan yang memiliki latar belakang agama, dalam hal ini tentunya agama Islam yang menjadi dasar pendidikannya. Dilihat lebih dalam, pendidikan Islam memiliki sebuah ajaran ataupun dasar berdasarkan ajaran-ajaran Agama Islam yang terkandung di dalam AlQuran dan Al-Hadist yang menjadi pokok penting. Hal ini tentu berkaitan dengan tujuan dari masuknya agama Islam itu sendiri yakni menyebarkan ajaran Islam untuk mencetak manusia yang senantiasa untuk selalu bertaqwa kepada Allah SWT demi tercapainya kebahagian baik itu didunia maupun diakhirat kelak. Hal ini tentu berbanding terbalik dan berbeda dengan pendidikan biasa atau pendidikan umum (Pratama \& Zulhijra, 2019).

Maka dalam sejarah berdirinya pesantren ini digunakan sebagai sarana dalam penyebaran agama Islam, kemudian lambat laun pesantren pun turut berkembang sebagai tempat untuk memperdalam ilmu agama Islam dan juga sekaligus berkembang menjadi salah satu sarana dalam mendidik dan mencerdaskan masyarakat Indonesia. Maka jika dilihat dalam perjalanannya tentunya pesantren sebagai lembaga pendidikan Islam sudah sangat eksis dari awal keberadaannya bagi masyarakat Indonesia bahkan hingga saat sekarang ini.

Kemudian secara umum kajian atau pembahasan yang membahas mengenai eksistensi dari lembaga pendidikan pesantren telah banyak yang melakukan, penelitian tersebut yakni diantaranya; Ahmad Royani (2018) membahas tentang eksistensi pendidikan pesantren dalam arus perubahan yang lebih menyoroti perubahan-perubahan dalam pendidikan pesantren. Kemudian Muh. Mustakim (2016) tentang eksistensi pesantren sebagai pusat pendidikan dan perubahan masyarakat bangsa indonesia di abad ke-19 dan abad ke-20 yang menekankan bahwa pendidikan pesantren ini berperan penting bagi bangsa Indonesia pada abad ke-19 dan abad ke-20, dan Sadali (2020) mengenai 
eksistensi pesantren sebagai lembaga pendidikan Islam yang mengutamakan pada pesantren sebagai ciri khas dari pendidikan Islam. Maka jika dilihat secara mendalam untuk penelitian yang membahas mengenai eksistensi dari pendidikan pesantren khususnya yang ada di Kota Palembang itu belum ada yang menyoroti, maka disini penulis menjadi tertarik untuk membahas tema tersebut.

\section{Metode Penelitian}

Di dalam tulisan ini, yang akan dibahas adalah mengenai eksistensi pendidikan pesantren di Palembang. Memuat mengenai sejarah dari pendidikan pesantren, metode yang digunakan dalam pendidikan pesantren, dan contoh dari lembaga pendidikan pesantren yang ada di palembang. Dalam penelitian ini menggunakan studi pustaka dengan sumber sekunder yang meliputi penggunaan dokumen seperti buku, makalah, maupun artikel. Kemudian jenis data yang digunakan yaitu data kualitatif. Data kualitatif inilah yang nantinya kemudian akan diolah menjadi data deskriptif yang berisi data-data tertulis dan saling berkaitan diantara satu sama lain sesuai dengan metode yang dipakai (Rasimin, 2018). Untuk langkah-langkah yang dilakukan oleh penulis yakni mengumpulkan bahanbahan berupa dokumen seperti buku dan artikel ilmiah yang terkait, membaca bahan-bahan (pustaka) yang telah dikumpulkan, membuat catatan untuk menarik inti dan membuat kesimpulan yang didapatkan dari bahan pustaka tersebut, dan mengolah hasil tersebut untuk disusun menjadi sebuah bentuk laporan penelitian.

\section{Pembahasan}

\section{Sejarah Perkembangan Pesantren}

Pesantren jika dilihat dari aspek historis pada awalnya merupakan pusat atau tempat dari penyebaran ajaran dakwah agama Islam pertama kali di Indonesia. Pesantren ini sendiri diduga telah ada sejak abad ke-13 M, kemudian seiring dengan perkembangannya pesantren menjadi cikal bakal dari lembaga pendidikan Islam yang tumbuh dan berkembang melalui daerah-daerah kecil atau pedalaman seperti desa. Namun seiring dengan berkembangannya zaman dan perubahan kehidupan manusia, fungsi pesantren sebagai pusat dari penyebaran ajarah dakwah agama Islam berkembang menjadi lebih kompleks. Tidak berarti juga bahwa tujuan utama pesantren yakni sebagai pusat dari penyebaran agama Islam hilang dan berganti. Berdirinya sebuah pesantren juga didasarkan 
latar belakang yang berlainan dan tentunya berbeda-beda, menyesuaikan dari kebutuhan masyarakat akan ajaran ilmu agama Islam. (Akhiruddin, 2015)

Kemudian di awal berdirinya pondok pesantren ini merupakan salah satu media ataupun sarana dari pembelajaran agama Islam yang sangat sederhana, belum terdapatnya pembagian kelas dan bahkan penggunaan pedoman belajar yakni kurikulum. Juga belum memiliki standar aturan atau aturan baku yang digunakan sebagai pedoman. Dalam hal ini peran kyai sebagai pemuka dan pengurus dari pesantren itu sendiri sangat dirasakan, tidak ada para santri ataupun murid yang meminta untuk mempelajari mengenai suatu kitab tertentu, tidak ada juga tuntutan atau keinginan dari santri dan murid mengenai materi yang ingin mereka pelajari. Semua hal ini mengikuti dan bergantung kepada wewenang yang dimiliki oleh seorang kyai itu sendiri sebagai pusat dari sistem pembelajaran pesantren (Masyhud, 2003)

Jika dilihat pada intinya dalam awal lembaga pendidikan pesantren ada di Indonesia, banyaknya ilmu yang didapat oleh santri maupun ilmu yang disampaikan atau diajarkan tergantung dari tinggi rendahnya ilmu daripada kyai itu sendiri, kemudian tergantung pada tingkat pemahaman dari santri, dan juga pedoman pembelajaran yang mana dalam hal ini kitab yang digunakan. Kekurangan yang terlihat jelas daripada sistem pendidikan seperti ini adalah belum adanya tingkatan atau jenjang pendidikan dan juga tahapan baku yang harus diikuti oleh para santri ataupun murid. juga masih dicampurnya sehingga tidak ada perbedaan antara santri lama dan santri pemula (Huda, 2015)

Umumnya karena hadirnya kyai disuatu daerah, kyai disini merupakan seseorang yang mempunyai ilmu agama yang tinggi. Sehingga para penduduk itu menjadi percaya dan mulai berguru ataupun belajar kepadanya, bahkan mereka turut mendirikan rumah atau tempat tinggal didekat rumah dari kyai tersebut. Selanjutnya jika kita mengkaji lebih dalam mengenai asal-usul dari berdirinya pesantren ini, ada 2 pendapat yang cukup kuat dilihat dari ensiklopedia Islam yang ada. Yakni pesantren berasal dari kumpulan orang yang melakukan sebuah tradisi guna melaksanakan amalan dari wirid dan dzikir dengan dipimpin oleh kyai. Mereka melaksanakan tradisi ataupun amalan ini dengan cara berdiam diri di masjid dalam beribadah dengan bimbingan dari kyai. Lambat laun tradisi beribadah di masjid ini berubah menjadi pengajian dan dari pengajian inilah turut pula berkembang lembaga pendidikan pesantren. Kemudian ada juga pendapat yang mengatakan bahwa 
pesantren ini ada karena mengadopsi dari model pendidikan agama Hindu-Budha yang telah ada terlebih dahulu di Indonesia (Akhiruddin, 2015)

Dalam awal perkembangannya pesantren memiliki 2 fungsi yakni sebagai sarana dakwah penyebaran agama Islam serta sebagai sarana pendidikan agama Islam walaupun tentu seperti yang kita tahu bahwa dalam pesantren itu sendiri mengalami perubahan seiring berjalan nya waktu. Pendidikan pesantren di Indonesia dapat dibilang cukup cepat dalam perkembangannya, dimulai dari awal abad ke-18 hingga abad ke-20 ini, dari masyarakat indonesia itu sendiri lembaga pendidikan pesantren ini menjadi lebih eksis dan semakin dapat dirasakan keberadaannya ditengah-tengah masyarakat luas. Hal ini pun menjadi nilai yang tentunya sangat positif. Hal ini sejalan dengan pendapat dari Zuhairini yang menjelaskan bahwa pesantren diprakarsai atau didirikan atas dasar kehendak seorang kyai dengan dibantu oleh masyarakat sekitar, pembangunan dilakukan di daerah sekitar masjid, mushalla atau langgar, dan surau sebagai bangunan utama untuk melakukan berbagai kegiatan agama dan sekaligus sebagai tempat tinggal dari para santri. Yang mana hal ini menjadikan bahwa para santri atau anak murid itu tidak perlu untuk kembali ke rumah masing-masing namun dapat menetap dan tinggal bersama dengan kyai (Usman, 2013)

Namun, kedatangan Belanda di Indonesia pun memberikan hambatan bagi perkembangan dari pesantren dikarenakan keinginan Belanda untuk menjajah Indonesia dan pesantren yang tentunya tidak tinggal diam bahkan turut melakukan perlawanan. Belanda datang dengan membawa pengaruh barat yang tentunya sangat menyimpang dari ajaran agama Islam. Pada masa kepemimpinan kolonialisme bangsa barat yakni pemerintah Belanda di Indonesia pengaruh westernisasi dan modernisasi yang dibawa membuat sikap lembaga pendidikan pesantren menolak dan menutup diri. Akibatnya pemerintahan Belanda melakukan pengawasan dan pembatasan yang ketat terhadap pesantren ini, dengan mengeluarkan beberapa kebijakan-kebijakan sebagai berikut:

1. Tahun 1882 pemerintahan kolonial Belanda yang ada di Indonesia mendirikan sebuah lembaga atau badan hukum berbentuk pengadilan agama yang memiliki tugas dan kewenangan untuk melakukan pengaturan dan pengawasan terhadap kehidupan beragama di dalam lingkungan pesantren. 
2. Tahun 1905 pemerintahan kolonial Belanda yang ada di Indonesia membuat sebuah peraturan yakni, dalam melakukan kegiatan pembelajaran, para guru agama yang ingin mengajar di Pesantren harus memiliki izin dari pihak pemerintahan kolonial Belanda.

3. Tahun 1925 pemerintahan kolonial Belanda yang ada di Indonesia membuat sebuah peraturan yang sangat ketat dan tentunya menyimpang lagi yakni, dalam melakukan kegiatan pembelajaran, dilakukan pembatasan terhadap guru yang ingin memberikan pelajaran mengaji guru dibatasi dan hanya tertentu saja yang dapat mengajar mengaji.

4. Dan pada tahun 1932 pemerintahan kolonial Belanda yang ada di Indonesia mengeluarkan sebuah peraturan yakni, pnutupan dan pemberantasan sekolah-sekolah keagamaan yang tidak memiliki izin dari pemerintah Belanda dan sekolah yang memberikan pembelajaran keagamaan yang berlawanan dengan perintah dari pemerintahan Belanda.

Hal ini tentu membuktikan bahwa betapa sulitnya dan begitu mengancamnya pendidikan keagamaan atau pendidikan Islam yang diberikan atau diajarkan di sekolahsekolah Islam seperti lembaga pendidikan pesantren pada saat itu bagi pemerintah kolonial Belanda. Namun berdasarkan dari data statistik yang ada pada pemerintahan kolonial Belanda tercatat bahwa pada tahun 1885 setelah belanda mendirikan lembaga peradilan agama, lembaga pendidikan pesantren justru menjadi berkembang mencapai 14.929 lembaga. Dan ditahun 1942 ketika masa pemerintahan dari pemerintah Jepang yang berkuasa di Indonesia berhasil mencatat jumlah total dari santri yang bersekolah di sekolah agama mencapai 139.415 orang. Apalagi ketika Indonesia telah merdeka dan melepaskan pengaruh penjajah, lembaga pendidikan pesantren ini semakin berkembang dengan cepat dan pesat (Usman, 2013)

Lanjut setelah periode dari kemerdekaan Indonesia di tahun 1945, pada tahun 1946 didirikanlah sebuah lembaga atau departemen keagamaan yang bertugas untuk mengatur mengenai masalah-masalah agama yang ada di Indonesia dan termasuk juga pendidikan agama pada saat itu. Pada tahun 1950 Kementrian Agama R.I yang diketuai pertama kali oleh K.H. Abdul Wahid Hasyim mengeluarkan sebuah peraturan yang mengatur mengenai "Pemberian kewenangan pelajaran umum bagi sekolah-sekolah keagamaan dan memberikan pelajaran keagamaan bagi sekolah-sekolah umum baik itu sekolah milik pemerintah dan milik pihak swasta. Tentunya akibat dari hal ini menjadikan adanya keterbukaan antara lembaga pendidikan yang ada di Indonesia, dan semakin membuat 
lembaga pendidikan pesantren menjadi terbuka serta berkembang hingga seperti sekarang ini. (Usman, 2013)

\section{Metode dan Tipe dari Pendidikan Pesantren}

Lembaga pendidikan pesantren sebagai salah satu corak dari pendidikan Islam tentu berbeda dengan lembaga pendidikan lain, baik itu dilihat dari sistem pendidikan dan kurikulum yang ada dan berlaku. Pesantren memiliki hal khusus yang melekat dalam pendidikannya yakni meliputi pondok, masjid, kitab-kitab, kyai, dan santri. Pesantren ini merupakan pendidikan Islam yang pertama kali ada di Indonesia. Dengan penyebaran yang terkenal dilakukan oleh para wali yang ada di pulau jawa, dengan cepat agama Islam dan pendidikan bercorak Islam dengan lembaga pendidikan pesantren berkembang ke daerahdaerah yang ada di Indonesia. Maka tentunya peran dari pesantren ini menimbulkan andil dalam mendidik dan mencerdaskan mengenai ilmu agama kepada masyarakat Indonesia pada saat itu. (Hasan, 2016)

Untuk itu metode yang digunakan dalam lembaga pendidikan pesantren, metode disini dimaksudkan yaitu merupakan sebuah cara atau komponen yang digunakan untuk membuat sebuah rencana yang dapat menjadi efektif dan efisien. Dalam hal ini tentunya rencana pengajaran di lembaga pendidikan pesantren, untuk itu penggunaan metode diharapkan dapat membantu membuat maksud atau tujuan menjadi lebih jelas. Sebagai sebuah lembaga pendidikan tentunya pesantren mempunyai beberapa metode dalam pengajarannya, dari mulai metode sederhana yang digunakan ketika masa awal masuk dan berkembangnya agama Islam hingga metode yang digunakan sekarang ini yang juga turut berkembang seiring waktu. (Faridah, 2019)

Baiklah untuk itu ada beberapa metode yang biasa digunakan dalam pendidikan pesantren, yakni metode wetonan yang mana dalam pembelajarannya semua santri duduk mengelilingi dan berada di dekat kyai yang berperan sebagai pemberi pembelajaran. Utnuk santri itu menyimak, memperhatikan sekaligus dapat mencatat jika dirasa ada yang perlu dan penting untuk dicatat. Kemudian ada metode sorogan yang mana dalam pembelajarannya dilakukan secara pribadi yakni para santri menghadap satu demi satu kepada kyai dengan membawa kitab yang akan dibaca. Terakhir yakni ada metode hapalan yang mana dalam pembelajarannya semua santri tanpa terkecuali mengahapal mengenai sebuah isi dari kitab, ataupun teks dan kalimat tertentu. (Zulhimma, 2013) 
Mengenai pendidikan di Indonesia, baik itu pendidikan umum maupun pendidikan Islam merupakan dua sisi bagian yang tidak dapat dipisahkan dan saling berkaitan untuk melengkapi tentunya. Hal ini berlaku dan tentunya masih bertahan hingga saat ini, apabila dilihat seiring berkembangnya zaman adanya keterbukaan antara pendidikan umum dan Islam yang meliputi pembaharuan pada pendidikan Islam dengan mengadopsi ketentuan dari pendidikan umum nasional, misalnya ada pembaruan berupa pembagian kelas-kelas yang turut diterapkan oleh pendidikan Islam seperti pesantren dan madrasah kemudian juga ada penerapan pembagian kurikulum nasional yang diberlakukan oleh lembaga pendidikan Islam. Hal ini secara tidak langsung membuat lembaga pendidikan Islam dalam pengajarannya itu bersifat terbuka demi mencapai tujuan pendidikan nasional Indonesia. (Sakir, 2014)

Namun hal ini bukan berarti pendidikan Islam seperti pesantren itu membuka dirinya seiring dengan perkembangan zaman. Apabila dilihat melalui tipe dari jenis pengajaran dan pendidikannya, maka pesantren dapat dibedakan menjadi 2 jenis yakni pesantren dengan tipe shalafiyah atau pesantren tradisional dan pesantren dengan tipe khalafiyah atau pesantren modern. Ada pesantren yang membuka diri terhadap pembaruan zaman dan ada yang membuka diri namun tetap mempertahankan tradisi atau nilai-nilai keaslian dari pesantren itu sendiri (Anas, 2012). Untuk itu penjelasan pembagiannya ini meliputi:

1. Untuk pesantren dengan tipe shalafiyah merupakan pesantren yang masih menjaga keasliannya sejak awal berdiri dan mempertahankan metode lama, pembelajarannya dilakukan melalui ajaran-ajaran lama atau tradisional dengan menggunakan penekanan terhadap kitab kuning. Peran kyai disini masih sangat penting yakni sebagai pembuat keputusan seperti pembagian jadwal didalam pesantren yang dibagi oleh kyai beserta kepengurusan pesantren. Hal ini juga membuat pesantren shalafi ini belum memiliki kurikulum.

2. Untuk pesantren dengan tipe khalafiyah merupakan pembaruan dari tipe pesantren shalafiyah, pesantren ini mennyesuaikan dengan perkembangan yang ada dan menerima permbaruan seiring perkembangan zaman dan dunia pendidikan. Di pesantren ini juga turut menggunakan pembagian tingkatan kelas seperti pada sekolah umum lainnya. Kemudian untuk pembelajaran kitab kuning tidak terlalu ditekankan kepada santri. Di pesantren ini pun telah ada kurikulum yang terdiri dari gabungan kurikulum umum nasional dengan kurikulum tambahan buatan dari pesantren. 


\section{Pesantren di Kota Palembang}

Baiklah agar lebih mengenal dan sesuai dengan judul ataupun tema yang dibahas yakni mengenai "Eksistensi Pendidikan Pesantren di Palembang" maka akan dibahas juga mengenai beberapa pesantren yang ada di kota Palembang sebagai pelengkap dan sebagai data pendukung atau tambahan terkait materi yang dibahas. Dilansir dari situs kemenag sumsel bahwa tercatat ada 32 pesantren yang aktif dan terdapat di kota Palembang. Namun disini akan diambil 3 contoh lembaga pendidikan pesantren dari tipe yang berbeda (tradisional \& modern) dan juga keberadaannya itu masih ada serta tetap eksis hingga saat ini sebagai salah satu lembaga pendidikan berbasis agama Islam di kota Palembang.

\section{Pesantren Rubath Al-Muhibbin}

Untuk pesantren Rubath al-Muhibbin ini berada di Jl. Lebak Murni, Rt. 022 Rw. 009, Sako Baru, Kec. Sako, Kota Palembang. Awal dari pendirian pesantren ini adalah sebuah inisiasi dari salah satu tokoh masyarakat yakni Habib Umar Abdul Aziz, di tahun 2001. Untuk Habib Umar ini sendiri juga merupakan salah satu alim ulama yang terpandang di Sumatera Selatan yang lahir di keluarga yang agamamis dan memiliki wawasan ilmu yang luas akan pendidikan Islam. Dalam perjalanannya pesantren ini didirikan bersama dengan melalui proses musyawarah yang diadakan beberapa pihak terkait seperti masyarakat sekitar, pemuka agama, dan juga pemerintah yang turut aktif memberikan bantuan. Kemudian untuk jenis dari pesantren Rubath ini sendiri adalah berbentuk pesantren shalafiyah atau pesantren tradisional dalam pendidikannya. Jika dirujuk lebih jauh mengenai kata dari "tradisional" disini berarti sebuah tatanan budaya ataupun adat yang ada dan telah berkembang di masyarakat. Maka hal tradisional disini dimaksudkan lebih terfokus kepada hal-hal yang bersifat lama dan masih terjaga (Hanif \& Haedari, 2006). Dalam pembelajarannya juga, pondok pesantren ini juga telah menggunakan pembagian jenjang kelas. penggunaan model pembelajaran sorogan dan wetonan yang terdiri dari 3 tingkat kelas yaitu I'dadim, Tsanawi, dan Aliyyah. Kemudian metode pengajaran yang diterapkan dalam pesantren Rubath al-Muhibbin ini menggunakan metode holaqoh, yakni metode yang mana pengajar dalam hal ini kyai dan guru lain duduk berada didepan para santri dan murid dalam mengajar atau memberikan materi. Untuk penggunaan kurikulum, yang diterapkan oleh pesantren ini sendiri merupakan buatan dari para staff guru yang mengajar. Kurikulum pesantren merupakan kurikulum yang berlaku wajib diterima oleh 
seluruh santri dan siswa tanpa terkecuali yang meliputi pembelajaran kitab suci Al quran, al-hadist, ilmu tafsir, bahasa arab, aqidah dan tauhid, akhlak dan tasawuf, dan sejarah Islam (Larasati, 2018).

\section{Pesantren Ar-Riyadh Palembang}

Pesantren Ar-Riyadh, terletak di Kota Palembang dengan alamat lengkap Jl. KH. Azhari No.59 Kec. Seberang Ulu II Kel. 13 Ulu Kota Palembang. Untuk itu lembaga pendidikan pesantren Ar-Riyadh ini memiliki 2 model atau bentuk lembaga pendidikan yakni berbentuk madrasah tsanawiyah (Tingkat SMP) dan madrasah aliyah (tingkat SMA). Namun sedikit berbeda dengan pondok pesantren Rubath, untuk pesantren Ar-Riyadh ini memiliki bentuk pesantren modern yang mana telah mengadopsi pembaruan didunia pendidikan. Peran dari kyai tidak lagi menjadi pusat dari pendidikan pesantren, namun digantikan dengan pendirian yayasan yang menaungi seluruh pengelolaan pesantren ini. Untuk penerapan dari kurikulum itu sendiri, pondok pesantren Ar-Riyadh ini sebagai salah satu lembaga pendidikan Islam tentu memiliki sebuah wewenang khusus untuk mengatur dan mengelola. Namun seperti yang telah dikatakan tadi bahwa pesantren ini telah membuka diri terhadap pembaruan yang ada di pendidikan, termasuk juga dalam pengelolaan kurikulum yang mana telah mengadopsi kurikulum dari departemen agama dan kementrian pendidikan. Penggabuan kurikulum ini antara kurikulum dari departemen agama, kurikulum dari kementrian pendidikan dan kurikulum pesantren membuat pesantren ini menjadi lebih siap untuk bersaing didalam dunia pendidikan dalam mencetak generasi penerus yang unggul. Namun sesuai dengan lembaga pendidikan pesantren yang mana pesantren ini lebih mengedepankan pendidikan Islam berbasis Al-quran dan Alhadist, pendidikan moral berbasis akhlak dan budi pekerti, serta beberapa pendidikan keterampilan (kursus) dan pendidikan umum. Namun selain pendidikan formal pihak pesantren Ar-Riyadh juga memberikan tambahan extrakulikuler untuk para santri atau siswa (Makruf, 2013).

\section{Pesantren Muqimus Sunnah Palembang.}

Pesantren Muqimus Sunnah beralamat di Jl. Depaten Lama Kel. 27 Ilir Kec. Ilir Barat II Kota Palembang, Sumatera Selatan. Pesantren ini didirikan pada tahun 2007 oleh K.H Zen Syukri dan anaknya Izza Zen Syukri, untuk K.H Zen Syukri ini merupakan salah satu tokoh dan ulama terkenal dari Kota Palembang, Sumatera Selatan. KH. Zen Syukri juga merupakan alumni dari pondok pesantren Tebuireng, Jawa Timur dan sekaligus 
merupakan murid dari KH. Hasyim Asy'ari. Untuk pesantren ini sendiri sekarang memiliki bentuk seperti sekolah pada umumnya, dan berarti telah mengadopsi pendidikan modern, namun pada praktiknya pesantren ini juga menggunakan berbagai kurikulum dan jenis surat kelulusan yang berlainan. Diantaranya ada 2 yakni kurikulum asli pesantren yang mana dalam penggunaan nya berpedoman kepada ajaran dari kitab kuning dan surat lulus dari pondok, kemudian ada kurikulum pemerintah yang surat lulusnya diberikan berdasarkan dari kemendikbud dan kemenag. Dalam perkembangannya juga pesantren saat ini terdiri dari 3 kampus atau sekolah yang dapat digunakan baik itu untuk kegiatan akademik dan kegiatan non akademik namun perlu diketahui bahwa untuk kampus yang pertama kali dibangun itu terletak di Jl. Depaten Lama, kemudian mengenai jenis pendidikan telah ada mengenai pembagian tingkat lembaga pendidikan yakni pendidikan Mts yang setara pendidikan umum SMP dan MA yang setara dengan pendidikan umum SMA. namun perlu diketahui bahwa untuk kampus yang pertama kali dibangun itu terletak di Jl. Depaten Lama, dan apabila kita lihat bahwa seiring dengan perkembangannya pondok ini masih dapat tetap eksis keberadaanya di masyarakat. (Okta Diansya, 2021)

\section{Kesimpulan}

Jika merujuk pada 2 penjelasan mengenai tipe atau jenis dari contoh pesantren yang ada yakni pesantren shalafiyah dan khalafiyah, maka sebagai contoh untuk pesantren dengan bentuk shalafiyah (tradisional) ada pondok Pesantren Rubath Al-Muhibbin yang terletak di Kota Palembang. Pesantren ini masih menerapkan metode pengajaran tradisonal khas pesantren dan kurikulum pembelajaran pesantren yang turut masih dibuat dan diatur berdasarkan ketetapan guru dan staf yang ada di pondok pesantren. Kemudian untuk Pesantren Ar-Riyadh merupakan salah satu pesantren yang telah membuka diri dengan mengikuti pendidikan modern yang ada. Terakhir ada juga dari Pesantren Muqimus Sunnah yang masih menggunakan pedoman kitab kuning namun juga telah membuka diri dengan mendirikan 2 jenjang lembaga pendidikan yakni pendidikan tingkat MTs. sederajat dan MA sederajat. Jadi pada pesantren ini baik pendidikan tradisional dengan pengajaran kitab kuning masih digunakan seiring dengan pengadopsian pendidikan modern. Maka dapat disimpulkan dari ketiga contoh pesantren ini, untuk wilayah Palembang sendiri lembaga pendidikan pesantren masih bertahan dan tetap eksis hingga sekarang ini. 


\section{Daftar Rujukan}

Agustin, R. (n.d.). Kamus Lengkap Bahasa Indonesia. Serba Jaya.

Akhiruddin, K. (2015). Lembaga Pendidikan Islam di Nusantara. Jurnal Tarbiya, 1(1), 195-219.

Anam, S. (2017). Karakteristik dan Sistem Pendidikan Islam: Mengenal Sejarah Pesantren, Surau dan Meunasah di Indonesia. JALIE: Journal of Applied Linguistics and Islamic Education, I(I), 145-149. https://doi.org/10.33754/jalie.v1i1.52

Anas, A. I. (2012). Kurikulum dan Metodologi Pembelajaran Pesantren. Cendekia: Jurnal Kependidikan dan Kemasyarakatan, 10(1), 29-44. https://doi.org/10.21154/cendekia.v10i1.400

Faridah, A. (2019). Pesantren, Sejarah dan Metode Pembelajarannya di Indonesia. AlMabsut Studi Islam dan Sosial, 13(2), 78-90.

Hanif, A., \& Haedari, A. (2006). Masa Depan Pesantren: Dalam Tantangan Modernitas dan Tantangan Komplesitas Global (2nd ed.). IRD Press.

Hasan, N. (2016). Model Pembelajaran Berbasis Pondok Pesantren Dalam Membentuk Karakter Siswa di Pondok Pesantren Raoudhotut Tholibin Rembang Jawa Tengah. Wahana Akademika: Jurnal Studi Islam dan Sosial, 3(2), 92. https://doi.org/10.21580/wa.v3i2.1146

Huda, N. (2015). Sejarah Sosial Intelektual Islam di Indonesia (1st ed.). Rajawali Pers.

Larasati, C. (2018). Profil Pondok Pesantren Salafiyah Rubath Al-Muhibbin Palembang. UIN Raden Fatah Palembang.

Makruf. (2013). Strategi Pondok Pesantren Arriyadh Palembang dalam Menghadapi Tantangan di Era Globalisasi. Universitas Muhammadiyah Palembang.

Defri, O. D., Syarifuddin, S., \& Alian, A. (2021). Perkembangan Pondok Pesantren Muqimus Sunnah di Kecamatan Ilir Barat II Kota Palembang Tahun 2009-2018. Skripsi. Universitas Sriwijaya.

Pratama, I. putra, \& Zulhijra. (2019). Reformasi Pendidikan Islam di Indonesia. Jurnal PAI Raden Fatah, 1(2), 117-127.

Sakir, M. (2014). Pendidikan Islam dalam Sistem Pendidikan Nasional. Cendekia: Jurnal Kependidikan dan Kemasyarakatan, 12(1), 103-118. https://doi.org/10.21154/cendekia.v12i1.369.

Sudrajat, A. (2018). Pesantren Sebagi Transformsi Pendidikan Islam diIndonesia. Vicratina: Jurnal Pendidikan Islam, 2(2), 64-88.

Sulthon Masyhud, M. (2003). Manajemen Pondok Pesantren. Diva Pustaka.

Usman, I. (2013). Pesantren Sebagai Lembaga Pendidikan Islam. Al Hikmah, XIV(1), 101119.

Zulhimma. (2013). Dinamika Perkembangan Pondok Pesantren di Indonesia. Jurnal Darul 'Ilmi, 01(02), 166-167. 